\title{
2 \\ Intellectual property rights in Papua New Guinea
}

\section{Leslie Harroun}

Intellectual property refers to the products, processes or discoveries that result from the human intellect. Examples include: inventions, works of art, computer software, medical technologies, musical compositions, geographical indications, engineering devices, plant varieties and soft drinks. Intellectual property laws give the originators of such products, processes or discoveries a limited private property right in the fruit of their labour. These rights are granted by governments. Intellectual property shares many of the characteristics associated with real and personal property-it can be owned, bought, sold, licensed, exchanged or given away. The only difference is that intellectual property is intangible; it cannot be defined or identified by physical parameters. Nonetheless, it must be expressed in some discernible way to be protected.

When a government grants an inventor an intellectual property right, it is rewarding that person for his or her creativity and encouraging them to disclose their new information to others through commercialisation. The sharing of information leads to the development of useful new technologies. Without the benefit of legal protection that intellectual property rights provide - and the profit that may follow as a result-an inventor may not be willing to share his or her product for fear it will be stolen or misused to benefit others. When this happens, creativity is stifled.

Intellectual property rights are expensive to obtain and maintain and are usually secured by large corporations who have the resources to develop, establish and protect them. Few individuals hold intellectual 
property rights. Thus, it is unlikely that intellectual property right regimes can provide the same benefits to developing countries that they do to industrial countries where large corporations have substantial resources to invest in technology development.

This chapter summarises the different classifications of intellectual property, what they protect and how, and their usefulness to Papua New Guinea today.

\section{The rationale for intellectual property rights}

Formal intellectual property rights provide an incentive for innovation and the public disclosure of new information. These are essential elements for the development and dissemination of valuable new technologies, including those related to medicine, agriculture and science. People who share the fruits of their labour with society are thought to be deserving of economic reward, granted by the state on behalf of society.

By providing economic rewards, intellectual property rights promote creativity and the sharing of information in a number of related ways. First, they reward people who create commercial or cultural value. Giving the originators of innovations or discovery an exclusive right to market or make a profit from their work encourages creative endeavour.

Second, intellectual property rights allow people to own the fruit of their labour. If something novel and beneficial is produced, society may decide to reward the innovator with some form of ownership of his or her creation. Although this takes the invention out of the public domain and increases its price to others, it encourages people to be creative by placing a value on their effort and providing them with a return for their labour.

Third, by satisfying the principles of moral or natural rights, intellectual property rights can give artists, inventors, traditional healers with biodiversity knowledge and other creative people a sense of parenthood toward their work or knowledge. This connection cannot be protected by traditional property rights because it is intangible. Yet, society can support this relationship by protecting it as intellectual property, thereby restricting the unauthorised use or destruction of useful inventions and knowledge.

Finally, intellectual property rights facilitate the acquisition and development of technology. The development and dissemination of new technologies is expensive and requires investment. Intellectual property 
rights encourage the development of new technology by offering investors a way to obtain financial returns. This has particular relevance in Papua New Guinea where the high genetic diversity is valuable because it can result in the development of new medicines and crops. If an investment in Papua New Guinea's genetic resources leads to a new medicine which is then protected as intellectual property, Papua New Guinea could benefit from any profits made by the medicine, as well as from the medicine itself. Without intellectual property laws, the inventor of the medicine may choose not to export the medicine to Papua New Guinea because his or her ownership interest therein would not be protected there (Gollin and Laird 1996).

\section{The classification of intellectual property rights}

There are five general categories of intellectual property in EuroAmerican law - trade secrets, patents, plant breeder rights, copyrights and trademarks. Each reflects the laws of the country in which it is enacted. Rights established in one country may not be protected or even recognised in another. Similarly, intellectual property laws are not extraterritorial; they do not automatically apply outside the country in which they are law. Despite existing agreements that attempt to harmonise intellectual property laws throughout the world, substantive differences exist, especially in laws governing patentable subject matter.

Although there is no universal agreement on the legal rights that accrue under each type of intellectual property, most countries generally recognise at least those that protect innovative products or processes and those that protect the unique expression of ideas.

\section{Protection of innovative products and processes}

Ideas, knowledge and know-how behind innovative products, processes and discoveries can be protected using trade secrets, patents and plant breeder rights. These types of rights give owners various rights of control over the use of their invention or discovery by others.

\section{Trade secrets}

Trade secrets are used to retain control over, and to prevent the disclosure of, an original invention or process. They protect confidential information and methods that give their owner a competitive advantage. Trade secrets have the potential to protect traditional 
knowledge of a medicinal plant, an extraction method handed down over generations or even taxonomic and ecological information and biological inventories (Gollin 1993). In order to be protected as a trade secret, an originator's information must

- be secret, in the sense that it is not generally known or accessible to persons who normally deal with that kind of information

- have commercial value because it is secret

- be kept secret through the use of reasonable steps taken by the person lawfully in control of the information.

Because trade secrets require both secrecy and evidence of efforts to maintain that secrecy (such as keeping a recipe locked in a safe), they are difficult to establish, protect and enforce. Trade secrets last as long as the information remains unknown. They may be licensed, disclosed or assigned by their owner, but anyone who uses a trade secret without permission and to their own advantage may be liable to its originator for any resulting profits. If the information is discovered by disclosure (by the originator), by independent discovery, accidentally, or by reverse engineering the trade secret is permanently extinguished.

A considerable amount of indigenous peoples' knowledge may be protected by trade secrets, as long as the information has commercial value and provides a competitive advantage. Even if landowners do not wish to commercialise exclusive information themselves, they may restrict access to their land and exchange the information with outsiders only under confidentiality agreements to obtain economic benefit for their knowledge (Posey and Dutfield 1996). Papua New Guinea has no legislation governing trade secrets, although common law received from the United Kingdom at Independence may apply (Nonggorr 1990).

\section{Patents}

A patent gives an originator the right to exclude others from making, using or selling his or her product, process or discovery, usually for ten and twenty years. In order to be protected by a patent, an invention must exhibit several characteristics.

- Specific utility -it must be a useful product or process. Knowledge itself, including ideas, theories and scientific formulas, is not patentable.

- Novelty - the invention must be recent and original and cannot have been previously known, used, made, patented, described in print or in a previously filed patent anywhere. In most countries (except the 
United States) the first person to apply for a patent receives it, whether or not she or he is the inventor.

- Non-obviousness or inventiveness-even if an invention is novel, it may not be patented if its discovery amounts to an apparent or obvious outcome of the prior art (previously known skill) in the subject matter or field. Mere discoveries are not patentable. The invention must be disclosed in a manner so detailed that it would allow a skilled technician to make or use it. A patent for an invented process may cover a non-obvious way of making something already invented or discovered. Similarly, a patent for an invented product does not require that it be made by a novel method.

Patents are commonly regarded as providing superior protection to trade secrets because inventors of patentable products or processes disclose their inventions so that others may learn from them, and because inventors do not have to expend effort to protect their knowledge from use by others. While this may be true in industrial countries, trade secrets are easier to obtain, protect more indigenous knowledge and are less expensive to enforce by individuals or communities with few financial resources. In addition, patent protection does not last forever; once a patent expires the owner loses his or her exclusive rights.

Countries differ widely in the patent protection they offer for living material. For example, in the United States novel genes, DNA sequences, plant parts or varieties and biotechnological processes may receive patent protection if they meet the above requirements. On the other hand, many developing countries exempt medicines, biological processes and products and agricultural technologies entirely from their patent regimes. ${ }^{1}$ One reason for this is to ensure public access to important inventions. However, such a restriction may prompt a foreign inventor not to export his or her technology to any country without patent protection, thereby reducing a developing country's access to that technology. In this situation, the developing country loses twice. While the diverse genetic resources of developing countries are exploited for biotechnology development - often with little financial gain-it is also the case that new technologies do not return to the country due to the lack of patent protection. In this way, lack of patent protection can severely limit the value of natural product development to a developing country (Axt et al. 1993). ${ }^{2}$

Some countries exempt biological processes from patent protection because they fear that a patent on a novel microbe, plant, cell line or purified compound will preclude people from using existing species or 
practicing traditional methods of medicine or agriculture. This is not true. While a patent may remove a novel species from the public domain, the wild species from which it was created remains available for use by everyone (Gollin 1993). Papua New Guinea has no legislation governing patents.

\section{Patents and indigenous knowledge}

Patents cannot be obtained for the discovery of products of nature. Accordingly, wild habitats, species and raw biological materials cannot be patented. As a result, much potentially useful indigenous knowledge about the uses of plants is not patentable because it relies on the properties inherent in naturally occurring organisms. However, products or processes resulting from the development of biodiversity are patentable in some countries. Some inventive preparations of natural substances may be sufficiently novel to be patented, and the patent would provide protection for the knowledge as long as the individual or group applying for the patent can be cited as the inventor (Posey and Dutfield 1996; Gollin 1993).

Unfortunately, patents are prohibitively expensive to obtain and enforce for most indigenous communities. A patent applicant must pay for the filing, examination and grant, which can amount to more than $A \$ 10,000-A \$ 15,000$ for each country in which the patent is registered (Whimp 1997a). Even if a community were to obtain a patent, it would be difficult to enforce. First, they would have to have knowledge of a violation by an outside individual, group or corporation, and then they would have to bring legal action against the infringer. Finding effective legal support and the financial resources to do so would be a considerable hardship for most indigenous people.

Many pharmaceutical companies have investigated potentially useful attributes of plants used for medicinal purposes by traditional communities. In some cases, they have patented an isolated active principle of a biological substance and used it commercially. Although a patent cannot be obtained for a naturally occurring organism, a new synthetic compound based on it, which may be more stable or less toxic than the original substance, may be patentable (Posey and Dutfield 1996).

In cases where a corporation uses indigenous knowledge to identify a useful substance without providing benefits, the local community can contest the patent. The community must show that the invention is 
based on information acquired from the group and was used without their permission. In most countries, patent applications are available to the public before the patent is awarded. The mere threat of a challenge to a patent application is often enough to make corporations more willing to compensate indigenous communities for their knowledge.

An indigenous inventor may also publish a detailed description of how to make an invention, which then becomes part of the prior art that the patent office is obliged to search before awarding a patent. This is called defensive publication and can be used to prevent outsiders from patenting inventions derived from indigenous knowledge or resources. The problem is that the original inventor would have to isolate the active ingredient of the invention and publish the details. Publication may also attract companies interested in exploiting a new product, without necessarily compensating the originator (Posey and Dutfield 1996).

\section{Petty patents}

Petty patents are similar to regular patents (otherwise known as utility patents) except qualification does not require the same level of inventiveness or non-obviousness. For example, a method for extracting a useful chemical from a plant in the Highlands of Papua New Guinea may be obvious given the international state of the art, but it may also be novel, useful and one step ahead of other methods. Petty patents are also less expensive to obtain because the patent examination process is either deferred or replaced by a registration system (Posey and Dutfield 1996).

Petty patents are designed to reward and provide incentive for less sophisticated inventions or discoveries. As a result, it may be easier to protect indigenous rights to biodiversity knowledge with a petty patent system. Petty patents typically last for seven to ten years.

Unfortunately, petty patents are only recognised within the country in which they are law; as yet there are no international agreements that recognise reciprocal rights to petty patents. One alternative for developing countries is to lower the standard of inventiveness for a utility patent in order to protect minor advances in technology and receive international recognition. However, though this may help protect traditional knowledge and local biodiversity, it may also open the door to substandard patents and remove useful products from the public domain (Gollin 1993). 


\section{Plant breeder rights}

Most countries exclude living organisms from patent protection. Plant breeder rights allow exclusion from producing or selling propagating material of new plant varieties for a period of 15 to 30 years. Under the 1961 international convention of the Union for the Protection of New Varieties of Plants, a breeder ${ }^{3}$ may earn the exclusive right to a novel plant variety if it is

- distinctive-distinguishable from other commonly known varieties by one or more characteristics

- uniform-homogeneous with regard to its sexual reproduction or vegetative propagation

- stable-remains true to its description after repeated reproduction and propagation

- novel-not sold or marketed with the permission of the breeder in the source country, or for longer than four years in any other country (Posey and Dutfield 1996).

Unlike patents, plant breeder rights allow the use of a protected variety for creating new varieties, for commercial exploitation and by farmers who wish to use their own harvested material to grow new crops on their own farms. For example, a farmer who purchased a protected plant variety could sell his or her crops commercially and plant new crops with the seeds produced from his or her harvest, but would be prohibited from selling the protected plant or its seeds. From this perspective, plant breeder rights are weaker than patents and would add little value to cultivars that come from wild habitats (Gollin and Laird 1996; Gollin 1993).

Plant breeder rights establish strict requirements for breeding. A new variety bred from a wild plant would normally require several generations of breeding before becoming eligible for protection. In addition, plant breeder rights require financial resources, legal experience and scientific facilities to carry out field trials, record results and otherwise demonstrate eligibility. As a result, it has been more common for professional breeders than traditional farmer-breeders, to take advantage of these rights. This, and the fact that the Union for the Protection of New Varieties of Plants Convention has few member states, means that plant breeder rights have little relevance worldwide. Papua New Guinea does not have plant breeder rights legislation. 


\section{Protection for the expression of ideas}

Some types of intellectual property rights protect the unique expression of ideas, symbols or devices rather than the ideas themselves. There is no exclusion of the right to use the ideas, but they may not be copied in their original form without authorisation. Copyright, trademarks and certification marks are the main examples of this type of intellectual property right.

\section{Copyright}

Copyright laws protect original works of authorship against copying. They cover literary works, dramatic and musical works, works of applied arts and crafts, maps and technical drawings, photographs, motion pictures and sound recordings, computer programs, compilations of genetic data and information in databases. These works must be published in a tangible form (oral information is not protected unless a recording is made). Protection typically lasts 50 years beyond the life of the author.

Copyright protection only covers the author's particular expression of his or her work in a tangible medium. Protection does not extend to the idea, procedure, process, system, method of operation, concept, principle or discovery, regardless of the form in which it is described, explained or embodied. For example, it would not be a copyright infringement to reorganise data from a number of sources into a new compilation, but it probably would be an infringement to copy a compilation outright. Copyright owners have a legal right to prevent others from reproducing their work, performing their work in public, making a recording of their work and broadcasting, translating or adapting their work.

Copyright protection in Papua New Guinea could be used to stop people from copying traditional arts, crafts, songs, designs and other cultural symbols without permission and acknowledgment of the source, or from passing off replicas of indigenous art as genuine. Copyright protection would not protect folklore that is passed on orally from generation to generation, and would only protect written or recorded folklore for a limited time period.

Similarly, copyright is not overly useful for protecting genetic resources. Data collected about species may be subject to copyright 
protection when included in publications or databases, but trade secrets, patents and plant breeder rights are more appropriate than copyright for protecting the genetic resources themselves. Copyright is assigned to individuals or companies, and so would have little use in protecting the rights of a community or clan.

Papua New Guinea passed copyright legislation in 1978, but it has never been implemented. The Copyright Act specifies that a work is not eligible for copyright unless deposit of the work has been made in terms of the Statutory Deposit Act of 1978. This latter Act was never passed. Depositories had to be identified, to hold all copyrighted works in the country before it could be passed, and the two potential depositoriesthe National Library and the University of Papua New Guinea Librarywere unavailable due to lack of funding and staff.

\section{Trademarks}

Trademarks prevent people from using confusingly similar words, names, symbols or devices in connection with the trade of goods to indicate who made the goods or provided the services and prevent deception and confusion in the marketplace. Trademarks protect the competitive advantage of providing a quality product or service, and ensure that the owners of a trademark obtain the profits associated with their product or service.

A trademark can last forever, but cannot be licensed or assigned apart from the goods or services it represents. Although trademarks do not have to be registered, doing so enables owners to license use and sue infringers. The Madrid Agreement Concerning the International Registration of Trademarks enables owners of trademarks to obtain coverage in multiple countries with a single application. Approximately thirty countries have signed this agreement (Posey and Dutfield 1996).

The artifacts and designs of indigenous peoples in Papua New Guinea are highly prized throughout the international market. Without trademark protection, indigenous people would have no recourse against those who make reproductions of their work and sell them as authentic. Consumers who value authenticity may choose to buy goods with an indigenous trademark even if they are more expensive than imitations. Some trademarks, such as the Body Shop, appeal to the ethical values of 
consumers as well by indicating that the purchase of a particular good supports a specific social or environmental cause. In addition, trademarks may deter potential imitators by threat of legal action.

Papua New Guinea has trademark legislation (Trademarks Act, Chapter 385). Trademarks are registered by the Registrar of Trademarks, who operates from the Investment Promotion Authority.

\section{Certification marks}

Similar to a trademark, a certification mark is attached to goods to indicate a certain quality to consumers. Unlike trademarks, certifications are granted by independent public or private organisations rather than the entity marketing the product or service. Examples include the Good Housekeeping Seal of Approval or sustainable timber certifications.

Individual regions or organisations within Papua New Guinea could certify that particular products, such as carvings authentic to a particular area of the Sepik or coffee grown by local villagers in the Crater Mountain Wildlife Management Area, were obtained in a sustainable manner. Once certified, these products should enjoy a competitive advantage among consumers around the world simply because they are linked to sustainable development and are perceived as green (Gollin 1993).

\section{Which intellectual property rights are suitable for local communities?}

No particular mechanism is ideally suited to collective ownership of traditional knowledge and biological resources. While some mechanisms are more suitable than others, they have all developed in a Western cultural and legal framework and are ill suited to this culturally different context.

\section{International law and intellectual property rights}

There are several international agreements and treaties to which Papua New Guinea is a signatory that require the implementation of intellectual property rights legislation. All are likely to affect the biological and cultural property rights of Papua New Guinea citizens. 


\section{The Convention on Biological Diversity}

In 1992, Papua New Guinea signed the Convention on Biological Diversity. This requires Papua New Guinea to develop plans, programs and policies to conserve and sustainably use its resources, to inventory and monitor national biodiversity, and to promote in situ and ex situ conservation. It also raises issues pertaining to cultural property rights, such as the protection of indigenous knowledge about medicinal resources and ownership rights to plant cultivars.

The Convention on Biological Diversity (Article 15(7)) directs its parties to promote 'the fair and equitable sharing of the benefits arising out of the utilisation of genetic resources,' and to take measures to 'respect, preserve and maintain knowledge, innovations and practices of indigenous and local communities embodying traditional lifestyles relevant for the conservation and sustainable use of biological diversity' (Article $8(j)$ ). In effect, the Convention seeks to promote conservation and sustainable development, and establishes the principle of reciprocity between access to the genetic resources concentrated in developing countries and access to the advanced technologies of the industrial countries. It expects that such measures will include mechanisms to govern prior informed consent, benefit sharing and local community control before access to such resources is provided.

A number of countries have already passed laws which implement the Convention on Biological Diversity. These laws have the following protections in common

- they assert national sovereignty over biological resources within national borders

- they require sample collectors to obtain prior informed consent, the scope of which would be defined via a permitting process

- they require benefit sharing, payment or some other consideration to the government as a condition of obtaining a collection permit.

In addition, many national laws include provisions that (Laird 1995)

- establish a national biodiversity board or administering agency

- require that rights of prior informed consent and benefit sharing extend to local communities

- encourage the transfer of technology

- require the use of contracts or materials transfer agreements for any transfer of genetic materials which contain terms for benefit sharing and technology transfer 
Intellectual property rights in Papua New Guinea

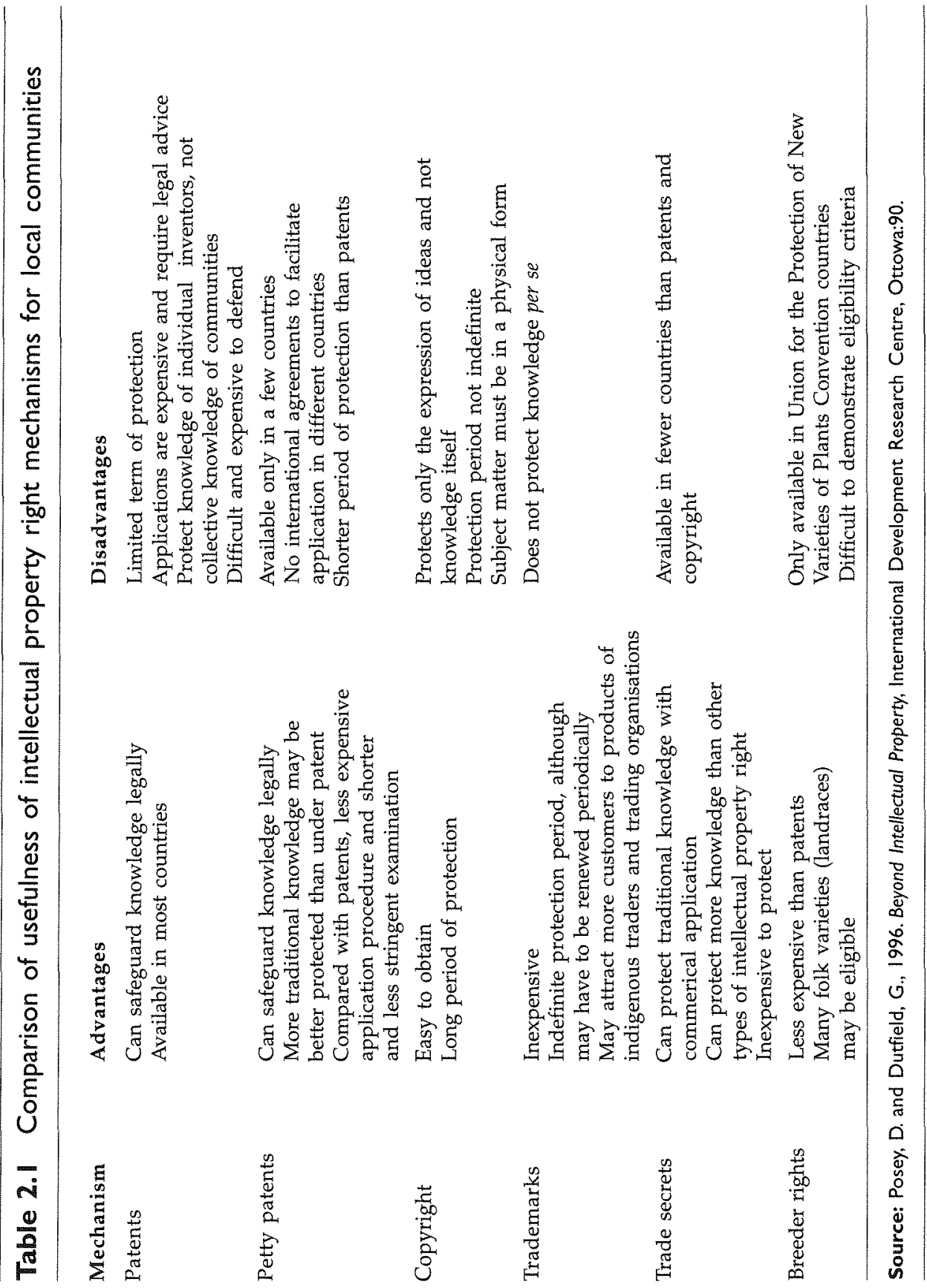


- require that any collection not endanger biological diversity

- require mechanisms to return benefits from exploitation to support the conservation of biological diversity.

The Convention on Biological Diversity provides international legal justification and a framework for Papua New Guinea to establish sovereignty over its genetic resources. It also encourages developing countries to implement intellectual property rights legislation. However, Western intellectual property models may be inappropriate and inadequate for Papua New Guinea at this point in time.

Intellectual property rights presume the desire and ability to commercialise products, processes or discoveries, which most indigenous people and communities do not possess. For many local communities in Papua New Guinea, art, songs, dances and plant knowledge represent more than intellectual property, and concepts of knowledge ownership are profoundly different from those of Western economics and jurisprudence. Traditional systems for sharing and transmitting knowledge and for regulating access to natural resources are extremely varied and most differ greatly from industrial societies.

While the language of the Convention on Biological Diversity and its associated agreements is vague regarding the rights of indigenous peoples, it provides an opportunity to define what those rights will be. As suggested by Posey and Dutfield (1996:104)

Given that indigenous peoples are recognised as having specific rights and benefits and that economic livelihood is linked to development and conservation of natural resources, as much energy and effort as possible should be put into activating the sections relevant to indigenous rights-especially the recognition and protection of, and compensation for, intellectual property. General Agreement on Tariffs and Trade negotiators, FAO, the WTO, and the World Intellectual Property Organisation will all have to accommodate to this reality in future because the vast majority of countries are signatories of the [Convention].

Overall, the Convention on Biological Diversity provides a framework that can help boost Papua New Guinea's negotiating strength in situations involving access to and development of its genetic and biochemical resources. However, Papua New Guinea has yet to incorporate the Convention into domestic policies or legislation. This means that under foreign property rights laws, biological resources still constitute common knowledge and are open to all. Through the Convention on Biological Diversity, Papua New Guinea now has the opportunity to develop the policies and legislation needed to achieve the 
benefits possible through development of its natural and cultural resources.

\section{The Trade-Related Aspects of Intellectual Property Rights}

\section{Agreement}

The Trade-Related Aspects of Intellectual Property Rights Agreement is an international agreement entered into under the framework of the General Agreement on Tariffs and Trade, to which Papua New Guinea is a signatory. It requires Papua New Guinea to meet minimum standards for protecting patents, copyright, trademarks and trade secrets and other related rights within a period of five to ten years.

The Trade-Related Aspects of Intellectual Property Rights Agreement is perhaps the most ambitious multilateral agreement to regulate intellectual property in the world. It incorporates provisions of the Paris Convention, the Berne Convention, and other international intellectual property treaties, and is based on the recognition that failure to provide adequate and effective intellectual property protection is a barrier to legitimate trade. ${ }^{4}$ The Agreement extends national treatment and most favoured nation treatment to countries with intellectual property protection.

The Trade-Related Aspects of Intellectual Property Rights Agreement has been strongly criticised by proponents of indigenous rights. They argue that developing countries are being pressured into accepting protection of plant genetic resources and limitations to access which are contrary to many customary practices of sharing seeds and community innovation. This is particularly true for plant breeder rights, which have the potential to encourage monocultures over in situ conservation and lead to negative implications for biodiversity. Yet within the TradeRelated Aspects of Intellectual Property Rights Agreement there is an opportunity to develop a sui generis (one of a kind) system for the protection of plant varieties that could serve the interests of local communities. In addition, the Trade-Related Aspects of Intellectual Property Rights Agreement excludes plants and animals from patentability, except for microoganisms and biological processes for the production of plants or animals (Article 27.3(b)), and allows countries to prohibit the patenting of commercial inventions that would lead to serious environmental prejudice (Article 27.2). In any event, it is possible under international law for indigenous people to demand that 
governments prohibit multinational corporations from patenting plant and animal material found on their lands.

Countries considering implementation of both the Trade-Related Aspects of Intellectual Property Rights Agreement and the Convention on Biological Diversity should examine how the two sets of laws interact. For example, if Papua New Guinea is interested in promoting natural product development it should consider greater patent protection for biotechnology inventions than the Trade-Related Aspects of Intellectual Property Rights Agreement requires. It should also consider enacting such legislation now rather than waiting the allowed five or ten years.

\section{The World Intellectual Property Organisation}

The World Intellectual Property Organisation, established in 1967, promotes international protection of intellectual property and facilitates international transfers of technology. Papua New Guinea became a member of the World Intellectual Property Organisation in November 1996.

As a United Nations specialised agency, the World Intellectual Property Organisation administers several multilateral intellectual property treaties, including the Paris Convention for the Protection of Industrial Property (1883), the Berne Convention for the Protection of Literary and Artistic Works (1886), the Madrid Agreement Concerning the International Registration of Trademarks (1891), and the Patent Cooperation Treaty (1970). The World Intellectual Property Organisation also provides assistance to signatory nations seeking to enact intellectual property laws and attempts to harmonise national laws throughout the world.

\section{Conclusion}

Intellectual property rights are useful to protect the products, processes and discoveries of human creativity and to encourage technological innovation. They become important when individuals (and corporations) want to make a commercial profit from their innovation or discovery. From this perspective, they protect purely economic interests. They are difficult, time consuming and expensive to obtain. Once secured they often have to be defended. They require elaborate national 
legal and regulatory institutions, including a patent and trademark office, copyright registry and a court system able to handle intellectual property cases. These all require substantial commitments of national funds and expertise.

Most developing countries do not have the resources to obtain or protect these economic rights, and therefore are unable to benefit from them even if recognised as law. In fact, most indigenous people and local communities would be put at a disadvantage relative to multinational corporations and other biodiversity end users if they tried to protect their knowledge and resources by employing these rights. Intellectual property rights are generally inappropriate and ineffective for defending traditional knowledge and resource rights, which are in large part linked to rights of self-determination. Fortunately, a number of alternative strategies for protecting indigenous knowledge and resources are emerging based on sui generis rights and restricted access to traditional cultural and biological resources.

Like most developing countries, Papua New Guinea has tremendous human and natural resources to nurture and promote. As a signatory to the Trade-Related Aspects of Intellectual Property Rights Agreement, the World Intellectual Property Organisation and the Convention on Biological Diversity, Papua New Guinea must make some immediate decisions about what types of intellectual property rights it wishes to embrace. It must think carefully about the impacts of each intellectual property right regime on economic policy, technology transfer, indigenous rights and biological diversity. It must make sure that its objectives are clearly incorporated into legislation and that they clearly address sources of conflict among these conventions. Papua New Guinea is a unique country and has the ability to define its own future-using intellectual property rights and sui generis rights wisely and creatively can help Papua New Guinea realise its future. 


\section{Notes}

1 A number of countries do not allow patents for pharmaceutical compounds or compositions: Argentina, Brazil, Egypt, Ghana, Honduras, Hungary, India, Iran, Iraq, Kuwait, Lebanon, Libya, Monaco, Norway, Poland, Portugal, Syria, Tangier Zone, Thailand, Tunisia and Turkey. Even more countries restrict patents for biotechnological processes and products: Brazil, Chile, Colombia, Denmark, European Patent Office, Finland, Great Britain, Hungary, India, Kuwait, Lebanon, Malaysia, Mexico, Nigeria, Peru, Romania, South Africa, South Korea, Spain, Taiwan, Thailand, Tunisia, Turkey, Uruguay and Yugoslavia (Gollin 1993, citing Baxter and Sinnot 1992).

2 Some people argue that the privatisation of the biotechnology industry and the recognition of property rights in biotechnology hinder access to these technologies by developing countries, who most need the benefits, presumably by making the cost of such technology exorbitant. For this reason, it is sometimes argued that intellectual property laws are irrelevant or even detrimental for developing countries (Dembo et al. 1985:431, 444 (note 62), 450-2).

3 Under the 1991 revision of the Union for the Protection of New Varieties of Plants, a breeder is a person who breeds, discovers or develops new crop varieties.

4 The Paris Convention for the Protection of Industrial Property (1883) directs that signatories must accord foreign patent and trademark applicants and owners the same treatment and rights as domestic patentees, although it does not grant any substantive international intellectual property rights. The Berne Convention for the Protection of Literary and Artistic Works (1886) establishes international standards for copyright protection. Member nations must provide protection for all copyrighted material, with minimal requirements for notice and registration, making copyright the simplest universal intellectual property rights system in the world. Papua New Guinea is not a signatory to either of these conventions, but will be required to adopt legislation that complies with them in order to meet its obligations as a member of the World Trade Organisation. 